\title{
Parasitological Characteristics of Schistosoma mansoni Infection in Swiss Mice with Underlying Malnutrition
}

\author{
Carla Simões/ ${ }^{++}$, Renata Heisler Neves, Lucas de Andrade Barros, Patrícia Dias Brito*, \\ Cristiane Oliveira Cravo*, Egberto Gaspar de Moura*/+++, \\ José Roberto Machado-Silva/ ${ }^{+} /+++$
}

\begin{abstract}
Laboratório de Helmintologia Romero Lascasas Porto, Disciplina de Parasitologia, Departamento de Patologia e Laboratórios, Faculdade de Ciências Médicas *Departamento de Ciências Fisiológicas, Instituto de Biologia Roberto Alcântara Gomes, Universidade do Estado do Rio de Janeiro. Av. Prof. Manuel de Abreu 444, $5^{\circ}$ andar, 20590-170, Rio de Janeiro, RJ, Brasil
\end{abstract}

The effects of a protein-restricted diet (8\% protein, $81 \%$ carbohydrate and $11 \%$ lipids) on Schistosoma mansoni infectivity, fecal egg excretion and intestinal egg distribution in Swiss (SW) mice were studied. Pregnant mice received a deficient diet from the middle of gestation until delivery. Seven-days-old mice were exposed to 50 cercariae (BH strain, Brazil). Offspring mice had a free access to the deficient diet since lactation until adulthood. The controls were fed with a commercial mice diet. A parasitological examination was performed between six and eight weeks post-infection while both groups were necropsied one week later. Mice on the experimental diet showed a significant loss in body weight. There was no significant difference $(p>0.05)$ in pre-patent period, kinetics of egg excretion and worm recovery from mice on either diet. Significant differences $(p<0.05)$ were found concerning to the percentage of deposited eggs in the distal segment of the small intestine from hosts on the experimental diet.

Our data suggest that experimental malnutrition induced for a long term has no detrimental effect on the acute schistosomiais infection in SW mice.

Key words: Schistosoma mansoni - biological study - malnutrition - lactation - Swiss mice

Malnutrition is the most prevalent form of nutritional disorder among children in developing countries. Protein malnutrition often occurs during gestation, lactation, and up to 2 years of life in humans. Besides the economic factors, the nutritional habits and lack of nutritional guidance lead to a prevalence of this type of malnutrition during gestation, lactation (or both) in developing countries (Desai et al. 1980, Onis et al. 1993). Some studies have shown that protein malnutrition during lactation is associated with thyroid dysfunction in the dams and that the mother's nutrition during lactation can determine the body weight of their offspring in adult life (Passos et al. 2002).

Schistosomiasis mansoni and malnutrition are often overlapping mainly in Northeast Brazil (Coutinho et al. 1997a). Malnutrition has been considered as a factor able to modify the host-parasite-environment system, aggravating the course of schistosomiasis by breaking the equilibrium in the relationships among the components of this system (Coutinho 1980). A deficient food blend with low protein-content (regional basic diet) had a negative effect on growth, food intake, reduced protein absorption and

This work is part of MSc Thesis on Morphology, Uerj, RJ, Brazil.

${ }^{+}$Corresponding author. Fax: +55-21-2587.6112. E-mail: machado@uerj.br

${ }^{++}$Fundação Carlos Chagas Filho de Amparo à Pesquisa do Estado do Rio de Janeiro Fellowship

${ }^{+++}$Conselho Nacional de Desenvolvimento Científico e Tecnológico Fellowship

Recieved 18 June 2002

Accepted 15 August 2002 failed to develop hepatic periportal fibrosis in schistosomiasis mansoni-infected mice (Coutinho et al. 1997b).

Most experimental studies concerning host nutrition and schistosomiasis mansoni demonstrate that malnutrition impairs normal adult worm growth whereas worm burden and egg production are reduced (Akpom 1982, Magalhães et al. 1986, Oliveira et al. 2001, Neves et al. 2001). Thus, this study was designed to evaluate whether acute schistosomiasis mansoni infection is changed in SW mice, whose mothers received protein-restricted diet and were maintained for a long-term under these conditions.

\section{MATERIALS AND METHODS}

Dams Swiss (SW) mice were supplied by Centro de Criação de Animais de Laboratório, Instituto Oswaldo Cruz (Rio de Janeiro, Brazil). The rodents were housed in polypropylene cages $(40 \times 33 \mathrm{~cm})$ with stainless steel screened covers. Pregnant mice received a protein-restricted diet (8\% protein, $81 \%$ carbohydrate and $11 \%$ lipids) from the middle of gestation until delivery. During lactation through adulthood, the offspring received free access to a protein-restricted diet until they were 68-daysold. A control (C) group received a balanced conventional pellet diet for mice (Nuvilab CR-1-NUVITAL Nutrientes Ltda., Colombo, Paraná, Brazil). Body weight was monitored twice a week. All mice had a free access to water. The experiments reported here comply with the current laws regarding ethical procedures with investigated animals and were approved by the IBRAG Ethical Committee.

Forty-nine, five-days-old mice were each one percutaneously exposed to 50 cercariae (BH strain, Belo Horizonte, Brazil). The cercariae were obtained from a reared-labora- 
tory Biomphalaria glabrata using artificial light.

For determining pre-patent period and kinetics of eggs releasing in feces, from 38 days post-infection until 57 days, feces were collected twice a week from each mouse individually. The feces were processed according to the Kato-Katz technique (Katz et al. 1972) and two slides per animal were inspected. The number of eggs detected in each slide was multiplied by 24 and expressed as eggs/g/ feces.

Sixty-three days after cercarial exposure, all animals were killed after cervical dislocation. Adult worms were recovered from the portal system and mesenteric veins. The gut was removed from mice for intestinal egg counts (oogram). For that, the small intestine was opened lengthwise and divided into two equal sections named proximal and distal segments. From each segment a sample $(1 \mathrm{~cm}$ long) was obtained. A same procedure was taken for colon segment (Machado-Silva et al. 1991). All fragments were crushed between two glass slides. The preparation was analyzed under brightfield microscopy (100X). Eggs were classified as described by Prata (1957). The resultant small intestine and colon were digested in $4 \%$ potassium hidroxide at $56^{\circ} \mathrm{C}$ (Cheever 1968) and centrifuged (2000 rpm) for $120 \mathrm{~min}$. Five $100 \mu \mathrm{l}$ aliquots of the digested tissue were counted in a glass slide under brightfield microscopy (100X). The data are reported as means \pm SEM and analyzed by Student's t test to determine which groups were divergent. The level of significance was set at $\mathrm{p}<0.05$.

\section{RESULTS}

The body weight was significantly $(\mathrm{p}<0.05)$ lower in malnourished mice than controls ones (Fig. 1). Eggs were first found in the feces (pre-patent period) on day 43 postinfection in both groups studied (Fig. 2). The kinetics of fecal egg-output was characterized by an increasing in the number of eggs with the duration of infection mainly for the malnourished group. Even by days 43 and 48 few eggs were found in controls mice. Between days 50 and 55 , a high egg-elimination was observed in both experimental groups. The number of eggs tended to decrease in the last fecal examination (on day 57) in control group whereas in malnourished mice seemed to reach a stable

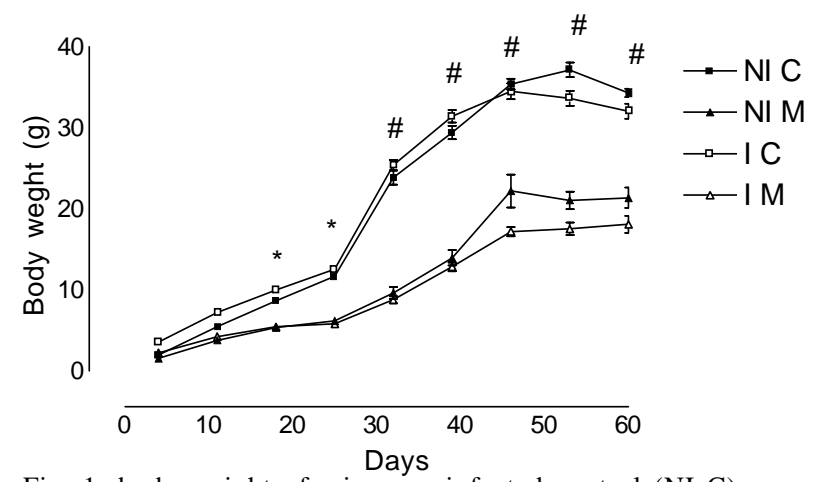

Fig. 1: body weight of mice non-infected control (NI C), noninfected malnourished (NI M), infected control (I C) and infected malnourished (I M) from day 4 to day $60 . * \mathrm{p}<0.05$ NI M vs NI C, I C; and I M vs I C, NI C; \# p < 0.001 NI M vs NI C, I C; and I M vs I C, NI C. phase with high egg-laying. Despite fecal egg counting was higher in malnourished animals no significant difference was found $(\mathrm{p}>0.05)$.

The tissue egg counts are given in Fig. 3. The proportion of immature and mature live eggs was similar between malnourished animals and controls $(p>0.05)$. A higher number of immature eggs were found in both experimental groups.

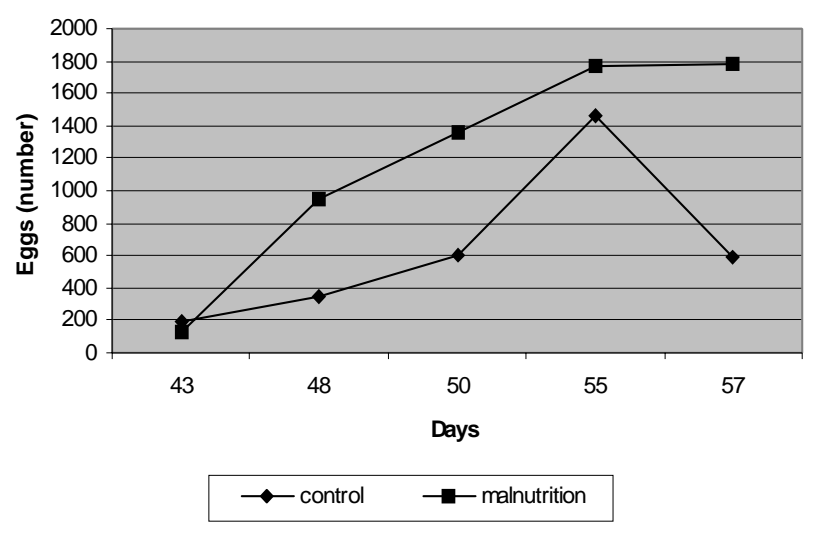

Fig. 2: kinectics of Schistosoma mansoni egg-laying in feces by means of Kato-Katz method of malnourished and controls Swiss mice.

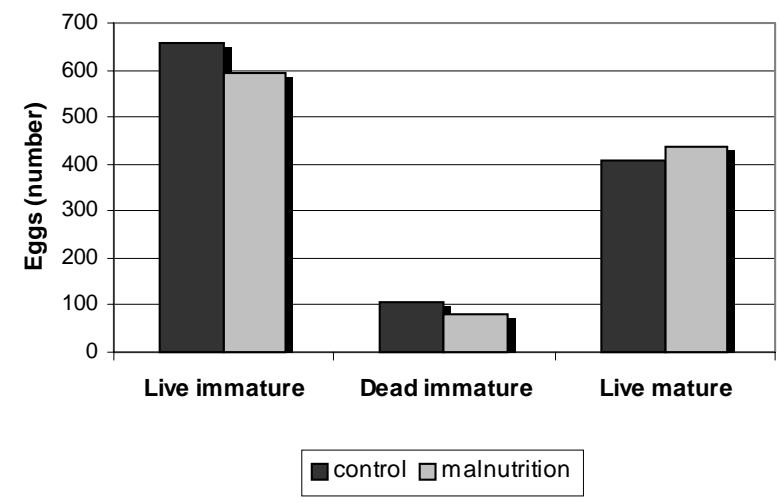

Fig. 3: intestinal egg count (oogram) of different types of eggs (live immature, dead immature and live mature) in the distal segment of the small intestine in malnourished and controls Swiss mice.

The egg distribution is given in Fig. 4. Both groups presented a greater percentage of eggs trapped in the upper portion of the small intestine (proximal segment). However, significant differences $(\mathrm{p}<0.05)$ were found in relation to the percentage of deposited eggs in the distal segment. Similar amount of worms were recovered from the mesenteric and portal veins of controls $(21.5 \%)$ and malnourished mice $(24.3 \%)$. No difference was found in the male/female sex-ratio (1:1).

\section{DISCUSSION}

The physiological relationship between $S$. mansoni and its host is complex and the details of several biochemical processes should still be determined (Neves et al. 2001). Contrary to convention, protein malnutrition 


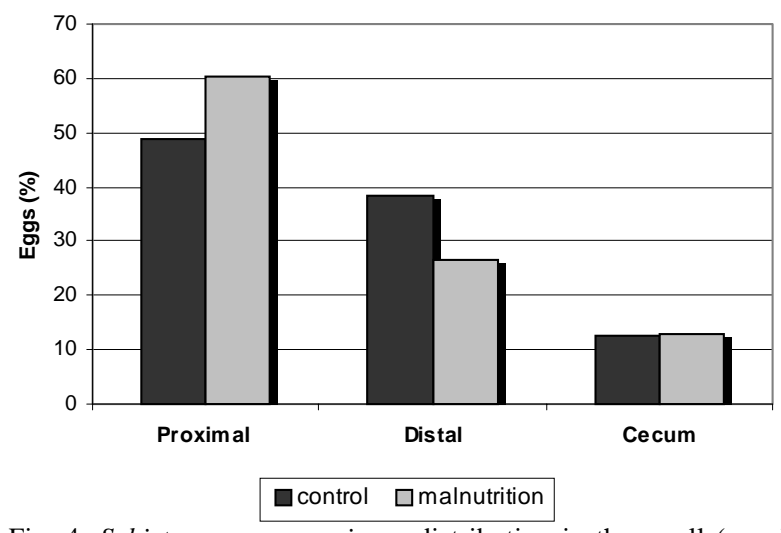

Fig. 4: Schistosoma mansoni egg distribution in the small (proximal and distal segments) and large intestine (cecum) of malnourished and controls Swiss mice.

did not affect its biological behavior since pre-patent period, the rate of maturation of adult worms, mate-finding and fecundity showed a similar behavior in both experimental groups (Akpom 1982, Rocha 1982, Ferreira \& Coutinho 1999). Given that the biological characteristics of the parasite were not affected due to malnourishment, it is important to stress some questions concerning factors that may influence egg-laying. The first aspect is based on the fact the migrating schistosomula possess ability to take up nutrients from the host (Brito et al. 2002). Hence, our results suggest malnutrition seem do not affect them.

Another aspect is that a protein deficient diet (regional basic diet) has a negative influence on the reproductive system of male adult worms. Furthermore, tegument has small thickness whereas tubercles is unevenly distributed, but kept grouped and flat while at the subtegumental level vacuolated areas were detected (Neves et al. 2001). Even though adult worms have extensive morphological changes, this is not enough to impair their reproductive capacity. Previous study has demonstrated that schistosomes adapt themselves to disturbances in the microenvironment by producing dwarf worms, which are able to mate and lay eggs (Wolowczuk et al. 1999). In addition, pairing is thought to be a prerequisite for the migration from the hepatic portal vein to the egg-laying site (Southgate et al. 1998). Also this behavior was not affected in malnourished mice because both experimental groups had similar pre-patent period. To our knowledge, for the first time pre-patent was evaluated in schistosomiasis mansoni-infected host with an underlying malnutrition. This way, our data ranged other publications using nourished mice (Anderson \& Cheever 1972, Fallon et al. 1997).

Everyone could speculate that malnourished male worms could have a limitation for locomotory movements since for this gender, the three major muscle system responsible for locomotory, alimentary and reproductive tracts are essentials (Mair et al. 1998). It is well established that in well-fed mice, S. mansoni eggs are trapped mainly in the small intestine (Nyndo \& Farah 1999). In this regard, about $50 \%$ of the eggs lodge in the distal segment of the small intestine (Costa \& Katz 1982, Machado-Silva et al. 1991). Meanwhile, our results showed that malnourished mice had a higher egg count in the proximal segment. Difference in the wandering capacity of malnourished worms inside the portal system vessels could be responsible for the observed results (Valadares et al. 1981). On opposite, it seems that schistosomiasis infection interferes with the process of intestinal protein absorption by potentiating the negative effects of malnutrition (Ferreira et al. 1993). It is particularly noticeable that dietary restriction induces morphological and physiological changes on the digestive tract. Malnourished rats subjected to prenatal dietary restriction had reduced body and organ weights (small intestine and colon). The small intestinal mucosa was hypotrophic with reduced mucosal thickness, villus height and crypt depth. Specific activities of lactase, maltase, sucrase and ileal hydrolase were decreased (Firmansyah et al. 1989, Chambon-Savanovitch et al. 1999).

It is widely believed that female schistosomes are metabolically more active than males (Tempone et al. 2002). Inadequate intake of nutrients leads to cessation of schistosome growth even though it is not clear how those factors interact with the parasite (Mendonça et al. 2000). In contrast to male worms, protein malnutrition seems not induce biometric alterations in uterine eggs studied in females isolated from malnourished mice (Neves et al. 2002). Therefore, reduction in oviposition and production of altered eggs may result in malnourished mice (Akpom 1982, Rocha 1982). However, our data presented here do not support these experimental studies showing physiological changes on the parasite.

One previous study performed in malnourished mice has shown that fewer eggs reached full maturity and more dead immature eggs were found when malnutrition was increased (Akpom 1978). In this present experiment, host environmental changes caused by malnutrition have no effect on the worm's ability to produce viable eggs, or on the development of the egg in the intestine tissue, in opposition to schistosome infection in mice with underlying experimental diabetes mellitus (Hulstijn et al. 2001).

Relatively few studies have examined the effects of malnutrition on the immune response in the parasite-infected host (Ing et al. 2000, Scott \& Koshi 2000). Nutrients have fundamental and regulatory influences on the immune response of the gastro intestinal tract and, therefore, on host defense (Cunningham-Rundles \& Lin 1998). Egg excretion in the feces depends on the host immune response and eosinophils favor the passage of schistosomal eggs to the intestinal lumen (Lenzi et al. 1987). Thus, mice deprived of their T-cells have fewer eggs in their feces (Doenhoff et al. 1978). Despite protein deficiency interferes with the immune status of the host (Fergunson 1994, Coutinho et al. 1997b), no significant change related to fecal egg excretion was found between both experimental groups. We are currently investing the histopathologic and morphometric characteristics of intestinal granulomas from these groups.

Apparently the host environmental changes caused by malnutrition have either an effect on the worm's ability to produce viable eggs, or on the development of the egg 
in the intestine tissue. The kinetics of fecal egg-output in both experimental groups were similar to other studies indicating an initial phase with low egg-shedding, another with increasing in the egg-laying and a later decreasing (Rocha et al. 1995, Ribeiro-Paes \& Rodrigues 1997, Thiongo et al. 1997). These data suggest that the egg passage through the intestine tissue was not hampered and its maturation did not seem to be affected. In malnourished mice fewer eggs reached full maturity and more dead immature eggs were found when malnutrition was increased during chronic infection (Akpom 1978).

In summary, our results demonstrated that protein malnutrition did not impair the biological behavior of $S$. mansoni adult worms. Most authors have studied an interrelationship between schistosomiasis mansoni and protein malnutrition over the post-weaning period (Akpom 1982, Magalhães et al. 1986, Coutinho et al 1992). In our study model, mice received free access to a protein-restricted diet throughout the experiment. It is probable that not only the host but the parasite also develop a certain degree of physiological adaptation to survive in a protein-deficient environment (Ing et al. 2000).

\section{ACKNOWLEDGMENTS}

To Dr Lygia dos Reis Corrêa for providing cercariae and Fátima Bastos for technical assistance.

\section{REFERENCES:}

Akpom CA 1978. The oogram as a sensitive method of assessing the effect of dietary deficiency on the parasite experimental Schistosomiasis mansoni. Trop Geogr Med 30: 219225.

Akpom CA 1982. Schistosomiasis: nutritional implications. Rev Infect Dis 4: 776-782.

Anderson LA, Cheever AW 1972. Comparison of geographical strains of Schistosoma mansoni in the mouse. Bull WHO 46: 233-242.

Brito CFA, Oliveira GC, Oliveira SC, Street M, Riengrojpitak S, Wilson RA, Simpson AJG, Oliveira RC 2002. Sm 14 gene expression in different stages of the Schistosoma mansoni life cycle and immunolocalization of the Sm 14 protein within the adult worm. Braz J Med Biol Res 35: 377-381.

Chambon-Savanovitch C, Felgines C, Farges MC, Pernet P, Cezard J, Raul F, Cynober L, Vasson MP 1999. Severe dietary restriction initiated in aged rats: evidence for poor adaptation in terms of protein metabolism and intestinal functions. Eur J Clin Invest 29: 504-511.

Cheever AW 1968. Conditions affecting accuracy of potassium hydroxide digestion techniques for counting Schistosoma mansoni eggs in tissues. Bull WHO 39: 328-331.

Costa MFFL, Katz N 1982. Comparative studies of Schistosoma mansoni strains isolated from patientes with toxemic or intestinal forms of Schistossomiasis. Am J Trop Med Hyg 31: 499-504.

Coutinho EM 1980. Estado nutricional e esquistossomose. Rev Soc Bras Med Trop 13: 91-96.

Coutinho EM, Abath FG, Barbosa CS, Domingues AL, Melo MC, Montenegro SM, Lucena MA, Romani SA, Souza WV, Coutinho AD 1997a. Factors involved in Schistosoma mansoni infection in rural areas of Northeast Brazil. Mem Inst Oswaldo Cruz 92: 707-715.

Coutinho EM, Ferreira HS, Freitas LPCG, Silva MR, Cavalcanti CL, Samico MJA 1992. Nutrition and acute schistosomia- sis. Mem Inst Oswaldo Cruz 87: 297-301.

Coutinho EM, Souza MM, Silva LM, Cavalcanti CL, de Araujo RE, Barbosa Junior AA, Cheever AW, Andrade ZA 1997b. Pathogenesis of schistosomal 'pipestem' fibrosis: a lowprotein diet inhibits the development of 'pipestem' fibrosis in mice. Int J Exp Pathol 78: 337-342.

Cunningham-Rundles S, Lin DH 1998. Nutrition and the immune system of the gut. Nutrition 14: 573-579.

Desai ID, Garcia Tavares ML, Dutra de Oliveira BS, Douglas A, Duarte FA, Dutra de Oliveira JE 1980. Foods, habits and nutritional status of agricultural migrant workers in Southern Brazil. Am J Clin Nutr 33: 702-704.

Doenhoff M, Musallam R, Bain J, Mc Gregor A 1978. Studies on the host-parasite relationship in Schistosoma mansoni infected mice: the immunological dependence of parasite egg excretion. Immunology 35: 771-778.

Fallon PG, Mubarak JS, Fookes RE, Niang M, Butterworth AE, Sturrock RF, Doenhoff MJ 1997. Schistosoma mansoni: maturation rate and drug susceptibility of different geographic isolates. Exp Parasitol 86: 29-36.

Ferguson A 1994. Immunological functions of the gut in relation to nutritional state and mode of delivery of nutrients. Gut 35 (Suppl.): S10-S12.

Ferreira HS, Coutinho EM 1999. Should nutrition be considered as a supplementary measure in schistosomiasis control? Ann Trop Med Parasitol 93: 437-447.

Ferreira HS, Coutinho EM, Teodósio NR, Cavalcanti CL, Samico MJA 1993. Intestinal protein absorption in malnourished mice with acute schistosomiasis mansoni. Mem Inst Oswaldo Cruz 88: 581-587.

Firmansyah A, Suwandito L, Penn D, Lebenthal E 1989. Biochemical and morphological changes in the digestive tract of rats after prenatal and postnatal malnutrition. Am J Clin Nutr 50: 261-268.

Hulstijn M, Oliveira RMF, Moura EG, Machado-Silva JR 2001. Lower faecal egg excretion in chemically-induced diabetic mice infected with Schistosoma mansoni due to impaired egg maturation. Mem Inst Oswaldo Cruz 96: 391-393.

Ing R, Su Z, Scott ME, Koski KG 2000. Suppressed T helper 2 immunity and prolonged survival of a nematode parasite in protein-malnourished mice. PNAS 97: 7078-7083.

Katz N, Chaves A, Pellegrino J 1972. A simple device for quantitative stool thick-smear technique in schistosomiasis mansoni. Rev Inst Med Trop São Paulo 14: 397-400.

Lenzi HL, Lenzi JA, Sobral AC 1987. Eosinophils favor the passage of eggs to the intestinal lumen in schistosomiasis. Braz.J Med Biol Res 20: 433-435.

Machado e Silva JR, Oliveira RMF, Rodrigues e Silva R, Maldonado Jr. A, Rey L 1991. Roedores silvestres como modelos experimentais da esquistossomose mansônica: Akodon arviculoides (Rodentia: Cricetidae). Rev Inst Med Trop São Paulo 33: 257-261.

Magalhães LA, Guaraldo AM, Zanotti-Magalhães EM, Carvalho JF, Sgarbieri VC, Alcântara FG 1986. Schistosomiasis mansoni in experimentally malnourished mice. Rev Saúde Públ 20: 362-368.

Mair GR, Maule AG, Shaw C, Halton DW 1998. Muscling in on parasitic flatworms. Parasitol Today 14: 73-76.

Mendonça RL, Escriva H, Bouton D, Laudet V, Pierce RJ 2000. Hormones and nuclear receptors in schistosome development. Parasitol Today 16: 233-240.

Neves RH, Machado-Silva JR, Pelajo-Machado M, Oliveira SA, Coutinho EM, Lenzi HL, Gomes DC 2001. Morphological aspects of Schistosoma mansoni adult worms isolated from nourished and undernourished mice: a comparative analysis by confocal laser scanning microscopy. Mem Inst Oswaldo Cruz 96:1013-1016. 
Neves RH, Oliveira SA, Machado-Silva JR, Coutinho E, Gomes DC 2002. Phenotypic characterization of Schistosoma mansoni adult worms recovered from undernourished mice: a morphometric study focusing on the reproductive system. Rev Soc Bras Med Trop 35: 405-407.

Nyindo M, Farah IO 1999.The baboon as a non-human primate model of human schistosome infection. Parasitol Today 15: 478-482.

Oliveira SA, Barbosa Jr. AA, Gomes DC, Machado-Silva JR, Montarroyos V, Barros AF, Coutinho EM 2001. The morphology and morphometry of adult Schistosoma mansoni recovered from undernourished infected mice. Rev Soc Bras Med Trop 34: 157-158.

Onis M, Monteiro C, Clugston G 1993. The worldwide magnitude of protein-energy malnutrition: An overview from the WHO global database on chlid growth. Bull WHO 71: 703712.

Passos MCF, Ramos CF, Dutra SCP, de Moura EG 2002. Longterm effects of malnutrition during lactation on the thyroid function of offspring. Horm Metab Res 34: 40-43.

Prata A 1957. Tipos de ovos de Schistosoma mansoni. In Biópsia Retal na Esquistossomose Mansoni, Serviço Nacional de Educação Sanitária, Rio de Janeiro, p. 15-60.

Ribeiro-Paes JT, Rodrigues V 1997. Sex determination and female reprodutive development in the genus Schistosoma: a review. Rev Inst Med Trop São Paulo 39: 337-344.

Rocha H 1982. Schistosomiasis and malnutrition. Rev Infect Dis 4: 783-784.

Rocha RL, Rocha MOC, Pedroso ERP, Colosimo EA, Coelho
PMZ 1995. Egg excretion in the initial phase of experimental murine schistosomiasis mansoni: stability and association with worm burden. Rev Inst Med Trop São Paulo 37: 325- 329.

Scott ME, Koski KG 2000. Zinc deficiency impairs immune responses against parasitic nematode infections at intestinal and systemic sites. J Nutr 130: 1412S-1420S.

Southgate VR, Jourdane J, Tchuenté LAT 1998. Recent studies on the reproductive biology of the schistosomes and their relevance to speciation in the Digenea. Int J Parasitol 28: 1159-1172.

Tempone AJ, Furtado DR, Gimba ERT, Oliveira FMB, Rumjanek FD 2002. Dolichol phosphate mannose synthase is differentially expressed in male and female worms of Schistosoma mansoni. Comp Biochem Physiol 131: 465474.

Thiongo FW, Madsen H, Ouma JH, Andreassen J, Christensen NO 1997. Host-parasite relationships in infections with two Kenyan isolates of Schistosoma mansoni in NMRI mice. J Parasitol 83: 330-332.

Valadares TE, Coelho PMZ, Pellegrino J, Sampaio IBM 1981. Schistosoma mansoni: Comparação da oviposição entre as cepas LE (Belo Horizonte), SP (São Paulo) e ST (Libéria) em camundongos. Rev Inst Med Trop São Paulo 23: 1-5.

Wolowczuk I, Nutten S, Roye O, Delacre M, Capron M, Murray RM, Trottein F, Auriault C 1999. Infection of mice lacking interleukin-7 (IL-7) reveals an unexpected role for IL-7 in the development of the parasite Schistosoma mansoni. Infect Immun 67: 4183-4190. 
